\title{
Helena Słotwińska
}

ORCID: 0000-0003-4473-3735

\section{Wzór osobowy nauczyciela gwarancją sukcesu edukacyjnego ucznia}

$\mathrm{W}$ badaniach nad wzorami osobowymi z psychologią, a w szczególności psychologią rozwojową i wychowawczą ściśle łączy się pedagogika. Miejsca dla wzorów osobowych w pedagogice należy szukać w powiązaniu z celami kształcenia i wychowania, jak też nauczycielami jako inicjatorami wyzwalania u uczniów pozytywnych relacji. Jednym z kierunków pedagogiki jest tzw. pedagogika postaci, określana także jako pedagogika spotkania ${ }^{1}$.

Dla realizacji podjętego tematu, którego celem jest wykazanie zależności między postawą nauczyciela a osiągnięciami ucznia, omówione zostaną dwie zasadnicze kwestie, a każdą z nich tworzą cztery zagadnienia szczegółowe: Nauczyciel jako wzór osobowy: 1. Pojęcie wzoru osobowego, 2. Postawa proegzystencji zasadniczą wartością w życiu i pracy nauczyciela-wychowawcy, 3 . Autoformacja przez samokształcenie i samowychowanie, 4. Pożądane cechy u nauczyciela-wychowawcy; Edukacja: 1. Pojęcie edukacji, 2. Wartości podstawą edukacji, 3. Zadania edukacji opartej na wartościach, 4 . Sukces edukacyjny ucznia.

$1 \quad$ Zob. M. Łobocki. Altruizm a wychowanie, Wydawnictwo Uniwersytetu Marii Curie-Skłodowskiej, Lublin 1998, s. 112-144. 


\section{Nauczyciel jako wzór osobowy}

\section{Pojęcie wzoru osobowego}

Według Encyklopedii katolickiej wzór osobowy to: „osoba, której cechy bądź czyny uważa się za godne naśladowania; model idealnego członka grupy społecznej (społeczności) wyznaczony przez zespół wartości lub norm, a także wyobrażeń związanych z pełnieniem ról społecznych i zawodowych"2.

W różnych naukach wzory osobowe są określane według specyfiki danej dziedziny wiedzy. W pedagogice personalistycznej i chrześcijańskiej osoba jest wzorem osobowym, jeśli realizuje w swoim życiu ideał doskonałości i swoje powołanie. Podkreśla się istotną rolę wzoru osobowego wychowawcy, zwłaszcza rodziców i katechety, lub postaci historycznej, a także świętych i błogosławionych. Wzór osobowy, jako postać uosabiająca wartości, wprowadza w ich świat, bazując na naturalnej tendencji młodych ludzi, do poszukiwania ideału godnego naśladowania. Wychowawcze oddziaływanie wzoru osobowego ma właściwości osobowościowotwórcze i uspołeczniające, a także pełni ważną funkcję rozwoju ich wiary i działania ${ }^{3}$.

Problem wzorów osobowych ${ }^{4}$ jest tym ważniejszy, że istnieje niebezpieczeństwo związane z pojawianiem się we współczesnej kulturze „autorytetów bezosobowych", które powodując się głównie względami komercyjnymi, propagują konsumpcyjną filozofię życia, a nawet kreują wręcz postawy nihilistyczne. Stąd - jakby na przekór niszczącym człowieka propozycjom - coraz bardziej ożywia się zapotrzebowanie na prawdziwe autorytety moralne, czyli wzory osobowe. Dokonana analiza istniejących w wielu źródłach określeń wzoru osobowego, wykazała następujące wymagania, jakie są im stawiane: 1) moralna doskonałość, 2) uosabianie, a nie tylko posiadanie pozytywnych przymiotów, 3) posiadanie wymiaru osobowego, społecznego i kulturowego, 4) bycie autorytetem, bez narzucania go siłą, 5) bycie ideałem osobowym, 6) wzbudzanie u wychowanków osobistego pociągu, 7) prowadzenie wychowanków

$2 \quad$ E. Jasińska, Wzorzec osobowy, wzór osobowy, [w:] E. Gigilewicz (red.), Encyklopedia katolicka, t. 20, Wydawnictwo Towarzystwo Naukowe KUL, Lublin 2014, kol. 1116.

3 Hasło: Wzór osobowy, [w:] J. Wojnowski (red.), Wielka Encyklopedia PWN, t. 30, PWN, Warszawa 2005, s. 1117.

4 Zob. H. Słotwińska, Wychowawcza wartość wzorów osobowych, Wydawnictwo Gaudium, Lublin 2008. 
poprzez odczucie duchowego pokrewieństwa (emocjonalne, intelektualne i wolitywne przylgnięcie), wypływającego z ich własnych duchowo-moralnych potrzeb i dążeń do przeżycia wyższych wartości oraz moralnego naśladownictwa, a także identyfikacji ze wzorem ${ }^{5}$.

Wymienione wymagania stawiane wzorom osobowym, pozwoliły wyodrębnić trzy obszary charakteryzujące nauczyciela-wychowawcę: a) postawa proegzystencji zasadniczą wartością w życiu i pracy, b) autoformacja przez samokształcenie i samowychowanie, c) pożądane cechy u nauczyciela-wychowawcy. W takiej kolejności zostaną zaprezentowane.

\section{Postawa proegzystencji zasadniczą wartością w życiu i pracy nauczyciela-wychowawcy}

Wychowanie wpisane w służbę osobowego życia i wzrastania człowieka powinno uwzględniać całość relacji, w jakie uwikłana jest jego egzystencja. Zatem cele wychowania, będą w stałej interakcji z tymi celami, które inspirują kontekst społeczny wraz z wartościami i normami społecznymi. Jednakże nie będzie to całkowite podporządkowanie wymiarowi społecznemu. Działanie autentycznie wychowawcze będzie dążyło nie tyle do wychowania człowieka w jakimś jednym rodzaju wychowania, lecz do wspierania go we wzrastaniu w człowieczeństwie i w działaniu na rzecz pobudzania do osobowego sposobu życia, czyli do „wzbudzania osoby”. Będzie zatem inicjacją, wprowadzaniem w życie oraz w postępowanie wolne i odpowiedzialne ${ }^{6}$. W tej pracy, w tym działaniu szczególną rolę odgrywa nauczyciel-wychowawca i jego proegzystencjalna postawa.

Termin „proegzystencja”, składa się z dwóch słów z języka łacińskiego: z przedrostka „pro” („na rzecz”, „na korzyść”, „w obronie”) i rzeczownika „exsistentia” (byt, istnienie, bytowanie) ${ }^{8}$.

Niniejsze określenie proegzystencji, zawiera bardzo ważną prawdę o osobie ludzkiej, będącej darem dla drugiej osoby. Człowiek bowiem,

$5 \quad$ Zob. Eadem, Wychowanie chrześcijańskie szansą integralnego rozwoju człowieka. Studium z pedagogiki religii, Oficyna Wydawnicza „Impuls”, Kraków 2019, s. 249-256.

6 Por. M. Nowak, Pedagogiczny profil nauk o wychowaniu. Studium z odniesieniami do pedagogiki pielegniarstwa, Wydawnictwo KUL, Lublin 2012, s. 319-320.

7 A. Jougan, Słownik kościelny łacińsko-polski, wyd. 3, Księgarnia św. Wojciecha, Poznań 1958, s. 541.

8 Ibidem, s. 246. 
który osiągnął swoją dojrzałość osobową, religijno-moralną, nie chce żyć egoistycznie, myśląc tylko o sobie, ale widzi swoje życie jako „dar dla", dla innych ludzi, dla rodziny, dla społeczeństwa, a szczególnie dla tych, którzy potrzebują pomocy.

W chrześcijaństwie proegzystencja to życie dla Boga i drugiego człowieka. Tak bowiem jak nie można rozdzielić przykazania miłości Boga od przykazania miłości bliźniego, tak samo chrześcijanin nie może rozdzielić „życia dla Boga”, od „życia dla drugiego człowieka”. Dla wcielania w życie człowieka, postawy proegzystencjalnej, fundamentalne znaczenie ma hierarchia wartości. Właściwe ułożenie jej wymaga uwzględnienia fundamentalnych pytań dotyczących celu i sensu życia ludzkiego, sensu cierpienia i śmierci; co ważniejsze: mieć? Czy być? Dobra materialne czy duchowe?

Z ideą proegzystencji spotyka się każdy człowiek bardzo wcześnie, bez względu na kraj zamieszkania, czy wyznawaną religię. Jako dziecko, od najwcześniejszych lat swojego życia, obserwuje zatroskanie rodziców o jego życie, zdrowie i wychowanie, powoli dochodzi do wniosku, że żyją oni nie dla siebie, ale przede wszystkim dla niego. Ponadto, każda praca, wykonywana dobrze i z pełnym zaangażowaniem, w której człowiek wychodzi poza siebie, poza swój „interes”, ma w pewnym stopniu wymiar proegzystencjalny.

Postawa proegzystencji stanowi postawę typową i uprzywilejowaną dla nauczyciela - wychowawcy. Historia zna wiele przykładów nauczycieli, którzy żyjąc całkowicie dla wychowanków, dawali im nie tylko wiedzę i różnego rodzaju stabilizację życiową, ale przede wszystkim dawali im całego siebie. Wystarczy wymienić takie wspaniałe postacie jak Janusz Korczak ${ }^{9}$, czy katolicki duchowny - ks. Jan Bosko ${ }^{10}$.

$9 \quad$ Janusz Korczak (Henryk Goldszmit), ur. 1878, zm. 1942: pedagog, lekarz, pisarz, działacz społeczny. Od 1912 roku kierował żydowskim Domem Sierot w Warszawie, współdziałał też z Marią Rogowską-Falską w Naszym Domu w Pruszkowie, a później w Warszawie. Podczas eksterminacji Żydów nie skorzystał z możliwości ocalenia. Wraz ze swymi wychowankami pozostał w warszawskim getcie, gdzie opiekował się nimi, zabiegając o żywność i przetrwanie, a następnie towarzyszył im do obozu koncentracyjnego w Treblince 6 sierpnia 1942 roku, gdzie w tymże roku zmarł. Korczak nie założył własnej rodziny, chcąc całkowicie oddać się pracy pedagogicznej, zgodnie ze swoją zasadą: „za syna obrałem ideę służenia dziecku i jego sprawie". J. Tarnowski, EK, t. 9, kol. 832-833).

10 Jan Bosko (1815-1888), ur. w pobliżu Castelnuovo, w diecezji turyńskiej. Dzieciństwo spędził w wielkim ubóstwie, a kiedy został kapłanem, wszystkie swoje siły 
Uniwersalny słownik języka polskiego, wychowawcą nazywa osobę wychowującą innych, kształtującą ich osobowość (1), względnie osobę opiekującą się przez dłuższy czas dzieckiem lub grupą dzieci; w szkole: nauczyciel opiekujący się klasą ${ }^{11}$. Wychowawca według Encyklopedii katolickiej to "główny podmiot wychowania, osoba projektująca oddziaływanie, organizująca i odpowiedzialna za jego przebieg oraz efekty"12.

Pojęcie „wychowawca” należy rozumieć bardzo szeroko. Pierwszymi wychowawcami są rodzice, a następnie domownicy stanowiący najbliższą rodzinę. Do grona wychowawców zalicza się osoby znaczące dla wychowanka z racji pełnionej funkcji, jak nauczyciel, przywódca religijny (katecheta), a także z powodu więzi emocjonalnej - przyjaciel, wzorzec osobowy, dalsza rodzina. W socjologii wskazuje się na społeczeństwo jako wychowawcę zbiorowego. W ujęciu teologicznym, zwłaszcza w okresie patrystyki Bóg był nazywany Wychowawcą Izraela, a następnie Kościoła. Tak przedstawiali Boga m.in.: św. Ireneusz († ok. 202), Klemens Aleksandryjski († przed 215), Grzegorz z Nysy $(† 394)^{13}$.

Funkcje wychowawcy i jego działalność wychowawcza zależą od przyjętej koncepcji człowieka, kontekstu środowiskowego oraz postawy (stanowiska) wobec wychowanka. Opiekun podejmujący się wychowania musi mieć przed oczyma cel tego procesu, treści przekazywane, strategie, metody, formy oraz zakładane rezultaty. Jego zasadniczym

poświęcił wychowaniu chłopców. Założył Zgromadzenie poświęcające się wychowaniu młodzieży. Napisał również drobne dziełka religijne. Zmarł w Turynie. Jakby podsumowując swoją ogromną pracę wychowawczą, podaje: „Zawsze postępowałem z miłością". A w swoich listach pisał m.in.: Jeśli rzeczywiście pragniemy prawdziwego dobra naszych wychowanków i przygotowania ich do wypełniania obowiązków, o tym nade wszystko powinniśmy pamiętać, że drogim naszym chłopcom zastępujemy rodziców. Dla nich pracowałem zawsze z miłością, dla nich uczyłem się, sprawowałem posługę kapłańską, zresztą nie tylko ja, ale i całe zgromadzenie salezjańskie (...). Tych, nad którymi sprawujemy jakąkolwiek władzę, uważajmy za synów. Stańmy się ich sługami, podobnie jak Jezus, który przyszedł służyć, nie zaś, aby Mu służono. Niech zawstydza nas nawet pozór chęci panowania. Nie panujmy nad nikim, chyba po to tylko, aby lepiej służyć": Z listów św. Jana Bosko, [w:] Liturgia Godzin, t. 3, Pallottinum 1987, s. 1082-1083.

11 Por. S. Dubisz (red.,) Uniwersalny słownik języka polskiego, t. 4, PWN, Warszawa 2003, s. 562.

12 M. Jeziorański, hasło: Wychowawca, [w:] E. Gigilewicz (red.), Encyklopedia katolicka, t. 20, Wydawnictwo Towarzystwo Naukowe KUL, Lublin 2014, kol. 1045.

13 Ibidem. 
zadaniem jest pobudzanie rozwoju wychowanka swoim własnym życiem, co niewątpliwie jest związane $\mathrm{z}$ pracą $\mathrm{w}$ trudzie i mozole nad samym sobą i formacją permanentną ${ }^{14}$. Praca bowiem nad sobą, czyli „wychowywać samego siebie, to odkrywać w słabości siłę, jaka jest mi dana, to także świadomość nadziei, która pozwala człowiekowi się podnieść i prowadzi do wiary, porządkującej wszystkie przeciwności”" ${ }^{15}$ Od wychowawcy wymaga się również „przejrzystości” względem wychowanka. Środkiem służącym przekazywaniu wartości jest zasadniczo zaufanie, które pozwala wychowankowi dostrzec w wychowawcy egzystencjalny punkt odniesienia, według którego będzie on mógł ukierunkować swoje życie. Najbardziej wyraźne, głębokie i trwałe ślady pozostawiają u wychowanka nie piękne słowa wychowawcy, a nawet nie jego argumenty, lecz uczynki świadczące o realizacji przez wychowawcę swoich wewnętrznych przekonań. W ten sposób wychowanek przekonuje się, iż zasady etyczne i światopogląd nie są czymś co się ma „za darmo", bez wysiłku, tak jak się ma ciało, albo jak się jest dzieckiem, młodzieńcem, albo jak się mówi swoim ojczystym językiem, lecz że istnieją one tylko dzięki osobistemu zaangażowaniu i są wynikiem codziennie podejmowanych odpowiednich (odpowiedzialnych) decyzji ${ }^{16}$.

Według filozofii realistycznej i osadzonej w niej personalistycznej koncepcji człowieka, relacja wychowawcy i wychowanka ma charakter zwrotny. Wyklucza przedmiotowe traktowanie wychowanka oraz umożliwia osobowy rozwój przez uczestnictwo w człowieczeństwie drugiego, co oddane jest w filozoficznych kategoriach określeniem spotkanie i dialog. Czymś charakterystycznym dla wychowawcy i wychowanka jest obustronna otwartość i zaangażowanie, co służy wychowaniu oraz urzeczywistnianiu człowieczeństwa w każdym z nich. Drogą prowadzącą wychowanka do odkrycia godności jest świadectwo

14 H. Słotwińska, Samowychowanie i samokształcenie elementami autoformacji, „Paedagogia Christiana" 2007, nr 1(19), s. 65-81; zob. także: H. Słotwińska, Kształtowanie postaw religijnych na katechezie, Katolicki Uniwersytet Lubelski, Lublin 2004, s. 272 oraz R. Guardini, Bóg daleki Bóg bliski, Wydawnictwo „W Drodze”, Poznań 1991.

15 D. Bis, Misja wychowawcza w ujęciu Romano Guardiniego, [w:] A. Rynio (red.), Wychowanie człowieka otwartego. Rola „Zmysłu religijnego” Luigi Giussaniego w ksztattowaniu osoby, Wydawnictwo Jedność, Kielce 2001, s. 259.

16 I. Verhack, Wychowywać czyli wzbudzać poznanie własnego istnienia, [w:] A. Rynio (red.), Pedagogika katolicka, Oficyna Wydawnicza Fundacji Uniwersyteckiej, Stalowa Wola 1999, s. 85-86. 
godnego życia wychowawcy. To świadectwo motywuje wychowanka do postępowania zgodnego $\mathrm{z}$ otrzymanym wzorem osobowym ${ }^{17}$.

Przewartościowanie swojego życia przez wychowawcę z egzystencji polegającej na życiu jedynie dla siebie, trosce o pomnażanie dóbr materialnych z pominięciem ludzi potrzebujących pomocy - na proegzystencję, czyli życie dla drugich, staje się w czasach powszechnie panoszącego się egoizmu, pierwszym wymogiem wobec autentycznego wychowawcy. Dzisiaj nie można już wychowywać tylko nakazami, zakazami czy autorytetem sprawowanego urzędu. Potrzebne jest świadectwo życia wychowawcy oddanego całkowicie, bez reszty wychowankom.

\section{Autoformacja przez samokształcenie i samowychowanie}

Wraz z rozwojem człowieka rodzi się potrzeba ciągłej konfrontacji subiektywnego rozumienia siebie z sądem obiektywnym społeczności nie tylko najbliższej, ale całego świata. Relacje te wpływają na możliwość zobiektywizowania obrazu człowieka i możliwości kształtowania jego postaw poprzez samokształcenie i samowychowanie ${ }^{18}$.

Biorąc pod uwagę samokształcenie, to jego bardzo precyzyjne określenie podaje Irena Jundziłł. Jej zdaniem „samokształcenie jest samodzielnym zdobywaniem wiedzy oraz umiejętności poza programem szkolnym, w celu zaspokojenia własnych zainteresowań"19.

Mechanizmem, który uruchamia samokształcenie są zainteresowania. Zainteresowanie jest to tendencja, skłonność człowieka do kierowania uwagi na określone przedmioty lub zjawiska. Nie ma zainteresowań bezprzedmiotowych, dlatego mają one zawsze charakter stosunku dwustronnego. Przedmiot, który budzi zainteresowanie, skłania do zajmowania się nim. Stąd też z zainteresowaniami związane są uczucia. Dzięki powiązaniu z uczuciami i świadomością znaczenia przedmiotu, nadają one kierunek wszystkim procesom psychicznym, stają się również motywem skłaniającym do działania ${ }^{20}$.

17 A. Maj, Wychowanie. Aspekt religijny, [w:] E. Gigilewicz (red.), Encyklopedia..., kol. 1041.

18 J. Tarnowski, Dojrzałość społeczna jako podstawa i wynik samowychowania, „Ateneum Kapłańskie" 1978, nr 86, s. 53; Zob. CT 45; DOK 171; PDK 97.

19 I. Jundziłł, O samowychowaniu, Wydawnictwo Nasza Księgarnia, Warszawa 1975, s. 171.

20 Ibidem, s. 168-169. 
Drugim, obok samokształcenia, i znacznie szerszym elementem autoformacji, jest samowychowanie, określane także jako praca nad własnym charakterem. Samowychowanie jest czynnym ustosunkowaniem się podmiotu do procesu własnego rozwoju, wyrażające się w regulowaniu swego postępowania i działania według dobrowolnie przyjętych wzorów lub systemu wartości ${ }^{21}$. Jest to świadome i celowe kierowanie sobą. Człowiek wychowując samego siebie, staje się podmiotem wychowania, jednostką zaangażowaną w działalność wychowawczą kierowaną na nią bądź na grupę, w której uczestniczy ${ }^{22}$. A zatem można najogólniej stwierdzić, że samowychowanie jest wychowaniem siebie samego przez siebie samego, w którym podstawą nie jest tylko rozwój przebiegający w zakresie biologiczno-psychicznym, ale zawierający się również w procesie samourzeczywistniania się.

W opinii Ireny Jundziłł „o samowychowaniu można mówić wówczas, kiedy aktywność własna jest skierowana na podmiot. Polega ona na czynnym ustosunkowaniu się człowieka do procesu własnego rozwoju i świadomej interwencji w ten proces"23.

Samowychowanie - według Encyklopedii aksjologii pedagogicznej ${ }^{24}$ to „zespół wewnętrznych i zewnętrznych czynności, podejmowanych przez osobę w celu pozytywnej zmiany samego siebie”. W celu uzupełnienia dodano także, iż

w samowychowaniu osoba kształtująca samą siebie, staje się aktywnym podmiotem własnych działań. Owa podmiotowość objawia się między innymi w autorefleksji, kierowaniu swoim postępowaniem, podejmowaniu decyzji wobec własnej osoby, dobrowolnym dążeniem do przezwyciężania własnych słabości i wad oraz rozwijaniem zdolności i innych walorów osobowych ${ }^{25}$.

W ujęciu chrześcijańskim, samowychowanie określone jest jako praca nad sobą. Oznacza ono staranie się o własny rozwój osobowy, to znaczy, o umocnienie pozytywnych cech osobowości i ich rozwój.

21 Z. Pietrasiński, Kierowanie własnym rozwojem, Państwowe Wydawnictwo Iskry, Warszawa 1977, s. 216.

22 I. Jundziłł, hasło: Samowychowanie, [w:] W. Pomykało (red.), Encyklopedia pedagogiczna, Wydawnictwo Fundacja Innowacja, Warszawa 1993, s. 716.

23 I. Jundziłł, O samowychowaniu..., s. 92.

24 A.J. Sowiński, hasło: Samowychowanie, [w:] K. Chałas, A. Maj (red.), Encyklopedia aksjologii pedagogicznej, Wydawnictwo Polwen, Radom 2016, s. 1026.

25 Ibidem. 
Dotyczy to także wrodzonych uzdolnień i posiadanych zainteresowań ${ }^{26}$. Praca nad sobą posiada cechy, które ją definiują. Utożsamia się ona z określonego rodzaju aktywnością ludzką wewnętrzną (np. samodoskonalenie na drodze kontemplacji), lub zewnętrzną (np. samodoskonalenie poprzez czyn). Zakłada pewien określony stopień dojrzałości psychofizycznej i społeczno-moralnej jednostki podejmującej tę aktywność. Jej charakter, przejawy i natężenie wiążą się w różnym stopniu z całokształtem warunków społecznych, w których jednostka żyje oraz z szeroko pojętą socjalizacją, obejmującą również wychowanie. Cele tej aktywności w różnym stopniu łączą się z koncepcjami, planami życia danej jednostki, a rozpatruje się je w kategoriach społecznych i moralnych. Aktywność w samowychowaniu cechuje różny stopień świadomości, dobrowolności, samodzielności w odniesieniu do wyboru celów, form i metod realizacji, kontroli wykonywania powziętego planu i przyjętego programu oraz oceniania wyników. Aktywność tę rozpatruje się zasadniczo w kategoriach procesu, a więc ciągu logicznie powiązanych ze sobą czynności, mających na celu wprowadzenie przez jednostkę zmian we własnej osobowości. Proces ten zachodzi, gdy jednostka odczuwa niezadowolenie z siebie, zaniepokojenie sobą i pragnie dokonać w sobie samej zmian, zgodnie z przyjętym przez siebie wzorem oraz wie, w jaki sposób może dokonać tych zmian, które przyniosą widoczne rezultaty ${ }^{27}$.

Praca nad sobą powoduje swoisty proces kształtowania własnej osobowości i postawy twórczej, która mając prawidłowe ustosunkowanie uczuciowo-drążeniowe do świata wartości, pozwala na podnoszenie własnego ludzkiego poziomu, to znaczy, na nieustanny wzrost ${ }^{28}$. Wyraża się on w zwalczaniu zauważonych u siebie wad i w rozwoju posiadanych zalet (cnót).

Istotne znaczenie ma także ukształtowanie odpowiedniej postawy wobec świata. Jest to postawa twórcza, oparta na żywej ciekawości

26 E. Sujak, Samowychowanie, [w:] Cz. Bartnik i in. (red.), Bóg-Człowiek-Świat. Ilustrowana encyklopedia dla młodzieży, Wydawnictwo Księgarnia św. Jacka, Katowice 1991, s. 252.

27 M. Dudzikowa, Praca młodzieży nad soba, Spółka Wydawnicza Terra, Warszawa 1993, s. 16; R. Wylie, The Self Concept, Oxford University Press, New York 1966, s. 22-32.

28 Por. M. Grzywak-Kaczyńska, Trud rozwoju, Instytut Wydawniczy PAX, Warszawa 1988, s. 63-66. 
poznawczej oraz chęci dążenia do coraz trudniejszych i bardziej odpowiedzialnych zadań. Właśnie taka postawa w sposób najbardziej sensowny łączy samowychowanie z samokształceniem. Umysł twórczy, niespokojny i dociekliwy, nie jest właściwością daną człowiekowi. Dopracowuje się go jednostka i kształci przez rozwijanie własnych zainteresowań oraz ćwiczy go przez ciągłe rozwiązywanie problemów ${ }^{29}$.

Człowiek powinien umieć określić swoje potencjalne wartości poprzez zrozumienie kim jest i przez znalezienie właściwego sposobu istnienia. Podstawowym warunkiem samowychowania jest nabycie świadomości, że jest się kimś odrębnym, nabycie świadomości siebie i informacji zgodnych z prawdą ${ }^{30}$. Ważną rolę spełnia odkrycie możliwości oddziaływania na siebie i świat.

Samowychowanie wiąże się z aktywnością samowychowawczą, rozumianą jako sfera refleksji etycznej (pojęcia, sądy etyczne, samoocena, aspiracje jednostki) i jako sfera działania, ujmująca w swym zakresie samodzielność w dążeniu do realizacji bliższych i dalszych celów ${ }^{31}$.

Celem człowieka winno stać się kształtowanie siebie wedle obrazu Boga-Ideału przez Jezusa Chrystusa - wymaga to trudu, cierpliwości i poświęcenia. Trzeba bowiem żyć Duchem Boga-Chrystusa, za Nim postępować i Go naśladować. Jeżeli człowiek chce siebie zrozumieć do końca, musi ze swoim niepokojem, niepewnością, a także słabością i grzesznością, ze swoim życiem i śmiercią przybliżyć się do Chrystu$\mathrm{sa}^{32}$. Przeniknięcie duchem Chrystusowym daje możliwość osiągnięcia celu doskonałości jako owocu autoformacji ${ }^{33}$. Doskonałością człowieka jako stworzenia Bożego, obdarzonego rozumnością i duchowością, jest kształtowanie w sobie obrazu i podobieństwa Bożego. Istotną rolę odgrywają tutaj łaska Boża, właściwy system wartości, pobudzenie i właściwa odpowiedź człowieka.

Chrystus jest najlepszym wzorem ludzkiej doskonałości. Wyraża się ona w osiągnięciu celu, jakim jest świętość i realizacja cnót. Należą do nich cnoty teologiczne (wiara, nadzieja i miłość), cnoty kardynalne

29 I. Jundziłł, O samowychowaniu..., s. 117.

30 T. Kukołowicz, Pomagamy w samowychowaniu, Wydawnictwo Nasza Księgarnia, Warszawa 1978, s. 42-44.

31 I. Jundzłł, Aktywizacja dziecka w procesie wychowania, Wydawnictwo PZWS, Warszawa 1966, s. 17.

32 Por. Encyklika Jana Pawła II Redemptor hominis z 4 marca 1979 roku, RH 13-17.

33 Por. Sobór Watykański II, Deklaracja o wychowaniu chrześcijańskim, DWCH 1-2. 
(roztropność, umiarkowanie, męstwo, sprawiedliwość) i cnoty heroiczne. Te ostatnie posiadają swój charakter moralny, obyczajowy i regulujący życie człowieka przez częste ich powtarzanie. Istotą cnoty bowiem jest akt o charakterze stałym. Cechą cnót heroicznych jest refleksyjność, łatwość w wykonywaniu aktów cnoty, radość w ich wykonywaniu ${ }^{34}$.

Źródłem mocy, która pozwala zrealizować postawione sobie cele jest Chrystus. On, który proponuje człowiekowi doskonałość i stawia Boga jako cel i wzór tej doskonałości, udziela siły do jej osiągnięcia, o ile człowiek otworzy się na nią, w szeroko rozumianym dialogu, zwanym modlitwą.

Należy jeszcze raz podkreślić, że aktywność własna rozpoczyna się już w niemowlęctwie i trwa aż do śmierci człowieka. Jej rozwój przez pierwszych kilkanaście lat wymaga wsparcia i pomocy zarówno ze strony rodziców jak i wychowawców. Nauka w szkole stwarza możliwości właściwego ukierunkowania aktywności własnej uczniów. Istotne jest to, aby nauczyciel potrafił uwzględnić w tym procesie fazy rozwojowe swoich wychowanków i aby sam swoją postawą świadczył o tym, jak ważną rolę odgrywa praca nad sobą w jego życiu. Taka postawa świadectwa daje szansę, że uczeń po ukończeniu szkoły rozpocznie samodzielnie wytyczać sobie cele i osiągać je przez samokształcenie i samowychowanie.

\section{Pożądane cechy u nauczyciela-wychowawcy}

Z określeń wzoru osobowego wynika, że nauczyciel powinien odznaczać się określonymi cechami, które warunkują skuteczność jego pracy. Ponieważ nauczanie powinno ściśle łączyć się z wychowaniem będzie chodziło o cechy nauczycielskie, dydaktyczne, a także o cechy dobrego wychowawcy. Katalog pożądanych cech jest bardzo szeroki ${ }^{35}$, ale zaprezentowane zostaną tylko te najistotniejsze i najczęściej wymieniane przez uczniów, a mianowicie:

34 A. Słomkowski, Ku doskonałości, Instytut Chrystusa Króla i Maryi Matki i Królowej, Warszawa 1993, s. 74-111; Por. J. Pastuszka, Charakter człowieka, Wydawnictwo KUL, Lublin 1962, s. 20; Por. S. Siek, Formowanie osobowości, Wydawnictwo Akademii Teologii Katolickiej, Warszawa 1986, s. 9-45 i 253-309. 
Cechy nauczycielskie:

Inteligencja. Nazywamy nią sprawność intelektualną jednostki, swoisty zespół zdolności umysłowych, które umożliwiają sprawne korzystanie z posiadanej wiedzy. Chodzi tutaj szczególnie o zdolność logicznego myślenia, o umiejętność trafnego dobierania środków prowadzących do osiągnięcia wytyczonego celu, o pewien krytycyzm wobec efektów własnego działania, o zdolność do łatwego przystosowania się do nowych warunków, nowych problemów i nowych zadań. Nauczyciel zatem powinien wykazywać się różnorodnością zainteresowań, które powinny go prowadzić do pilnego czytelnictwa, poszerzającego horyzonty myślowe i dającego orientację w szerokiej problematyce.

Wiedza. Nauczyciel winien być świadomy, jak ważną rolę w jego przygotowaniu odgrywa zdobywana wiedza; winien pamiętać o celu swego przygotowania, które ma służyć nie tylko jego własnemu rozwojowi, ale skierowane jest do służenia innym (proegzystencja). Przede wszystkim jednak chodzi o docenianie kształcenia permanentnego. Ograniczenie się do wiedzy zdobytej w trakcie studiów prowadzi w każdym zawodzie do stagnacji. Gdy w grę wchodzi jakiekolwiek nauczanie, brak stałego dokształcania prowadzi do rutyny, skostnienia, braku efektywności dydaktycznego działania.

Uporządkowany przekaz. Uporządkowane myślenie nauczyciela oznacza panowanie nad posiadaną wiedzą, która nie przytłacza i nie wywołuje poczucia zagubienia. Oznacza też umiejętność rozróżniania między rzeczami istotnymi a drugorzędnymi. Dla jasności ważna jest umiejętność budowania pewnej struktury swego nauczania, przejrzystej, logicznej kompozycji etapów, stopni, po których idąc nauczyciel doprowadza uczniów do przyjęcia pewnego kompendium wiedzy. Porządek i jasne myślenie umożliwia przyjęcie właściwego modelu lekcji oraz dobrą orientację w zagadnieniach metodycznych. Brak tej cechy prowadzi do chaotycznego przekazu, co z kolei uniemożliwia osiągnięcie zamierzonego celu lekcji.

Umiejętność przekazywania wiedzy. Chodzi tu o pewne umiejętności dydaktyczne, których można się nauczyć przez opanowanie teorii i doświadczenie praktyki. U podstaw tej umiejętności leży pewna skłonność do obdarzania mniej dojrzałych i mniej wiedzących uczniów i wychowanków tym, co się samemu posiada i uznaje. Sama umiejętność zaś zasadza się na znajomości sposobów, które najlepiej 
prowadzą do przekazania posiadanej wiedzy, i to w tym wyraźnie uświadomionym celu, aby wspierać rozwój ucznia. Chodzić tu będzie o odpowiednią formę podawania wiedzy, z uwzględnieniem dostosowania się do myślenia ucznia na różnych etapach jego rozwoju, o pewną sztukę wyjaśniania, tłumaczenia, uprzystępniania tego, co sprawia uczniowi trudności. Ponadto, chodzi tu również o umiejętność rozkładania procesu dydaktycznego na szereg etapów, prowadzących konsekwentnie do głębszego poznania podawanych wiadomości. Realizacja tych etapów dydaktycznych wymaga pomysłowości i twórczego ustosunkowania się nauczającego do wyznaczonych zadań edukacyjnych.

Panowanie nad mową. Chodzi tu najpierw o ogólną kulturę języka, którym posługuje się nauczyciel, a więc o posługiwanie się językiem poprawnym i jasnym. Posługiwanie się językiem gwarowym, slangiem środowiskowym nie powinno mieć miejsca w szkolnym nauczaniu. Cechą ułatwiającą nauczanie jest też płynność mowy, do czego potrzebny jest odpowiedni zasób słów. Pojęcia, którymi posługuje się nauczyciel, winny być ścisłe i dokładne. Żywość mowy wypływa z emocjonalnego zaangażowania nauczyciela - co eliminuje męczącą monotonię. Dopiero, gdy jego mowa jest przeniknięta zasadami logicznego myślenia, jest on w stanie istotnie coś przekazać. Swoje znaczenie w przekazie słownym ma też piękno języka. Istnieje również mowa mimiki, gestu, zewnętrznej postawy nauczyciela - w gruncie rzeczy o wielkiej sugestywności. Nauczyciel więc winien dużo czytać, aby nabywać poprawności językowej i wzbogacać swój zasób pojęć i słów.

Podzielność uwagi. Uwaga jest procesem ukierunkowania czynności poznawczych na pożądany przedmiot, zjawisko, wydarzenie. Odznacza się koncentracją myśli na określonych treściach, podczas gdy inne pozostają poza polem świadomości jednostki. Uwaga podzielna jest zdolnością do jednoczesnego zwracania uwagi na kilka obiektów. Nauczycielowi prowadzącemu zajęcia w grupie bardzo przydatna jest uwaga podzielna do realizacji zadań dydaktyczno-wychowawczych. Najpierw dlatego, że rytm pracy poszczególnych uczestników grupy nie jest jednolity, a nauczyciel musi zadbać o to, aby wszyscy przyswoili sobie podawaną wiedzę i aby wszyscy w grupie poddani byli oddziaływaniu wychowawczemu. Poza tym dla właściwego realizowania zadań dydaktycznych potrzebna jest w grupie atmosfera porządku, skupienia i zaangażowania we wspólnej pracy. Podzielna uwaga nauczyciela pozwala mu obejmować całą grupę i korygować we właściwy sposób 
zachowanie uczestników grupy. Posługiwanie się uwagą podzielną przez nauczyciela ułatwia również dobre przygotowanie się do zajęć, opanowanie tematu oraz realizowanie planu lekcji.

\section{Cechy wychowawcy:}

Autorytet. Gdy mówimy, że ktoś ma autorytet, chcemy powiedzieć, że jego wpływ na innych zostaje przez nich uznany. Gdy jest mowa o wychowawcy z autorytetem, rozumiemy, że dzieci i młodzież darzą go szacunkiem, liczą się z nim i poddają się jego wpływom. Można rozróżnić autorytet obiektywny i autorytet subiektywny. Autorytet obiektywny wynika z uznanej funkcji, jaką jednostka pełni w danej społeczności. Autorytet subiektywny jest uznaniem i szacunkiem, które wychowawca, katecheta zdobywa sobie u wychowanków na podstawie swej wiedzy, doświadczenia, ze względu na cechy swego charakteru.

Życzliwość. To jedna $\mathrm{z}$ istotnych cech wychowawcy, element nieodzowny we wszelkim oddziaływaniu wychowawczym. Życzliwość skłania wychowawcę do zajmowania się wychowankami, do przebywania z nimi, poświęcania im czasu, nieżałowania trudu. Mieści się w niej chęć pomagania innym, szczególnie tym niedojrzałym, aby posiedli na własność to wszystko, co dla wychowawcy jest wartościowe i cenne. Mieści się w niej także cierpliwość i wyrozumiałość wypływające ze świadomości, że wychowanie jest procesem długotrwałym. Życzliwość wobec wychowanków nie oznacza słabości - wychowawca jest zdecydowany i stanowczy, gdy w grę wchodzą wartości.

Takt pedagogiczny. Jest to umiejętność takiego obcowania z wychowankami, aby nikogo nie obrażać, nie wywoływać uczucia przykrości, nie powodować konfliktów. Chodzi tu więc o pewną delikatność w kontaktach z innymi, o szacunek okazywany każdemu wychowankowi. Przykłady taktu pedagogicznego nauczyciela-wychowawcy, to: nie lekceważy się żadnej wypowiedzi, błąd poprawia się w sposób niedotykający autora wypowiedzi; nie wyróżnia się nikogo w sposób ostentacyjny; nie pyta się o sprawy bardzo osobiste; nie używa się obraźliwych określeń w stosunku do wychowanków. Przez takt pedagogiczny wychowawca nawiązuje z wychowankami więź przyjaźni. Pomocą w wypracowaniu w sobie taktu pedagogicznego jest prawdziwa znajomość samego siebie, szacunek dla godności każdego człowieka, idea poświęcania się dla pracy z dziećmi i młodzieżą. 
Znajomość wychowanków. Chodzi tu przede wszystkim o znajomość praw rządzących procesami wychowawczymi, o zapoznawanie się z teoretycznymi zasadami wychowania, które są owocem doświadczeń innych wychowawców, szczególnie uzdolnionych i refleksyjnych. Ważne jest również poznawanie wychowanków przez własną obserwację. Potrzebna jest do tego pewna umiejętność spostrzegania i oceny. Wchodzą tu w grę najdrobniejsze szczegóły życia psychicznego wychowanka. Przy obserwacji należy zatroszczyć się o obiektywizm, bezstronność w ocenach postępowania wychowanka, co nie jest łatwą sprawą, szczególnie dlatego, że kontakt wychowawcy z wychowankiem jest bardzo bliski, w związku z czym istnieje możliwość oddziaływania na ocenę wychowanka całej sfery emocjonalnej wychowawcy. Potrzebna jest też wychowawcy świadomość ograniczoności własnej oceny, stąd gotowość do korekty, do zmiany zdania pod wpływem innych danych czy zdania innych wychowawców.

Pragnienie wychowawczego wpływu. Jest to jakby poczucie pewnej misji, którą wychowawca odczuwa jako wewnętrzną skłonność i potrzebę wpływania na innych, kształtowania ich, urabiania według wzorców uznawanych przez niego za wartościowe. Ta wewnętrzna skłonność przejawia się w pewnych cechach wychowawcy, które wyznaczają sposoby jego postępowania. Chodzi oczywiście nie tylko o wewnętrzną skłonność do wpływania na wychowanków, ale też o umiejętność wywierania wychowawczego wpływu. Według Kreutza wychowawca posiada tzw. cechę sugestywności, która oznacza pewność siebie, spokój i odwagę w działaniu, zwłaszcza w sytuacjach trudnych; głęboką, niedopuszczającą wątpliwości wiarę w siebie, we własne zdolności, w prawdziwość swych przekonań, wartość swych ideałów, wreszcie bezkompromisowe i prostolinijne dążenie do realizowania swych celów, a także sprawiedliwość i konsekwencję.

Łatwość nawiązywania kontaktu. Cecha ta polega na umiejętności zgrania się wychowawcy z wychowankami. Kontaktowość jest warunkiem oddziaływania wychowawczego. Jeśli wychowawca nie ma dobrego kontaktu, jeśli między nim a wychowankami zaistnieje antypatia i brak zaufania, działania wychowawcze będą nacechowane antagonizmami i konfliktami. Nie ma dobrego kontaktu wychowawczego, gdy istnieje wzajemna obojętność. Niewłaściwe są też dwie skrajne postawy wychowawcy w odniesieniu do wychowanków: z jednej strony, 
stosunek władczy, bezwzględnie autorytatywny, domaganie się ślepego posłuszeństwa, stosowanie przymusu; z drugiej, schlebianie wychowanków, zbytnie spoufalanie się, zabieganie o popularność. Właściwie pojęta kontaktowość wychowawcy oznacza wzajemne zaufanie i szacunek, sympatię, życzliwą, ale wymagającą przyjaźń.

\section{Edukacja: pojęcie, wartości, zadania, sukcesy ucznia}

\section{Pojęcie edukacji}

Edukacja - łac. „educatio” oznacza: a) „uczenie kogoś lub uczenie się, zwłaszcza w szkole; kształcenie, nauka; b) „kształcenie u kogoś określonych postaw i reakcji; wychowywanie"36.

Według Nowego słownika pedagogicznego - edukacja, to „ogół procesów i oddziaływań, których celem jest zmienianie ludzi, przede wszystkim dzieci i młodzieży - stosownie do panujących w danym społeczeństwie ideałów i celów wychowawczych".

Edukacja - „wyprowadzić, wyciągnąć, poprowadzić, wychować” to, podstawowe pojęcie w pedagogice, obejmujące ogół wielowymiarowych działań oraz procesów służących wychowaniu i kształceniu osób czy grup społecznych ${ }^{37}$.

Edukacja to także „symboliczna komunikacja wyrażona w języku umożliwiającym rozpoznawanie, rozumienie, akceptowanie i respektowanie wartości nadających sens ludzkiemu życiu"38.

Natomiast edukacja religijna - ze względu na pluralizm religijny nie posiada jednej definicji. W odniesieniu do

tradycji chrześcijańskiej edukacja religijna otwiera horyzonty i wspomaga człowieka w rozwoju dążącym ku dojrzałości religijnej. Do istotnych miejsc przekazu

36 Hasło: Edukacja, [w:] S. Dubisz (red.), Uniwersalny słownik języka polskiego, t. 1, Wydawnictwo Naukowe PWN Warszawa 2003, s. 787.

37 B. Śliwerski, hasło: Edukacja, [w:] C. Rogowski (red.), Leksykon pedagogiki religii. Podstawy - Koncepcje - Perspektywy, Wydawnictwo Księży Werbistów „Verbinum”, Dragacz 2004, s. 132.

38 J. Gnitecki, W poszukiwaniu aksjologicznych podstaw edukacji, [w:] U. Ostrowska (red.), Edukacja przełomu wieków wobec kwestii aksjologicznych, Wydawnictwo Uniwersytetu Warmińsko-Mazurskiego, Olsztyn 2001, s. 21; Zob. W. Zalewska, Kulturoterapia jako edukacja aksjologiczna, [w:] K. Olbrycht (red.), Edukacja aksjologiczna. Wymiary - Kierunki - Uwarunkowania, Wydawnictwo Uniwersytetu Śląskiego, Katowice 1994, s. 92. 
wiary zalicza się: rodzinę, jako środowisko elementarnego wychowania religijnego, szkołę, jako przykład humanistycznego i chrześcijańskiego wykształcenia oraz parafię, jako miejsce tożsamości religijnej, komunikacji i nauczania międzypokoleniowego ${ }^{39}$.

Wiara i życie wiarą są dla chrześcijan nieustanną pomocą, zwłaszcza w szukaniu odpowiedzi na pytania religijne, w dokonywaniu wyborów między dobrem a złem, w rozwiązywaniu problemów egzystencjalnych i ostatecznych, takich jak: sens życia, sens cierpienia i śmierci, czy los człowieka po śmierci.

\section{Wartości podstawą edukacji}

Wartości stanowią podstawy aksjologiczne dla edukacji. W dziedzinie edukacji bezwzględnie jest potrzebne miejsce na wartości, czyli miejsce zarówno na wartości w nauczaniu, jak i w wychowaniu. Edukacja rozpoczyna się od rozeznania wartości oraz ich typologii.

Według Encyklopedii katolickiej, wartość to „cecha przedmiotu materialnego lub niematerialnego czyniąca go cennym, użytecznym i pożądanym, zależna od jego roli w zaspokajaniu potrzeb i społecznym procesie wymiany; jest ważnym kryterium stosowanym przy ocenie zachowań, zdarzeń i ludzi"40.

Encyklopedia aksjologii pedagogicznej stwierdza, iż wartość, to „podstawowa kategoria aksjologii oznaczająca wszystko, co cenne i godne pożądania, co stanowi cel dążeń ludzkich, co uważane jest za ważne oraz sprzyjające i w takiż sposób urzeczywistniane. Wartości występują tylko w antroposferze i mogą zaistnieć wówczas, gdy człowiek dokonuje aksjologizacji świata"41.

W procesie wychowania najbardziej właściwe jest obiektywistyczne rozumienie wartości, czyli założenie, iż wartości nie mają charakteru relatywnego, zależnego od doświadczającego podmiotu. Przeciwne takiemu ujęciu jest stanowisko subiektywistyczne, które utożsamia dziedzinę wartości ze sferą doznań psychicznych, relatywizując wartość względem podmiotu.

39 C. Rogowski, hasło: Edukacja religijna, [w:] C. Rogowski (red.), Leksykon..., s. 140.

40 E. Gigilewicz (red.), Encyklopedia katolicka..., kol. 216.

41 U. Ostrowska, hasło: Wartość, [w:] K. Chałas, A. Maj (red.), Encyklopedia aksjologii..., s. 1304; Zob. także U. Ostrowska, Aksjologiczne podstawy wychowania, [w:] B. Śliwerski (red.), Pedagogika, t. 1: Podstawy nauk o wychowaniu, GWP, Gdańsk 2006, s. 396. 
Istotnym zagadnieniem aksjologii jest sposób istnienia wartości. Podejmując rozwiązanie niniejszego zagadnienia, należy zauważyć, że w tym temacie występują dwa przeciwstawne stanowiska, a mianowicie: subiektywizm i obiektywizm aksjologiczny. Subiektywizm aksjologiczny reprezentują m.in. Epikur i Kant. Obejmuje on poglądy subiektywizmu w sensie ścisłym, poglądy relatywizmu i sceptycyzmu. Subiektywizm w sensie ścisłym polega na podmiotowym nadaniu rzeczom wartości w aktach świadomościowo-przeżyciowych. Natomiast relatywizm aksjologiczny podkreśla względność wartości, czyli ich zmienność w zależności od miejsca, czasu, okoliczności podmiotu wartościującego. Sceptycyzm wyraża niemożność poznania wartości będących wyrazem pragnień i potrzeb ludzkich. Obiektywizm aksjologiczny przez swoich przedstawicieli jak np. Sokrates, Platon, Arystoteles, św. Tomasz z Akwinu, Tomasz More, Max Scheler, Hildebrand, Nicolai Hartmann, Józef Tischner, zdecydowanie przeciwstawia się subiektywizmowi i relatywizmowi aksjologicznemu. Twierdzi bowiem, że wartości istnieją niezależnie od podmiotu i jego zachowań, oraz że są bezwzględne, absolutne, a nie względne, przypadłościowe ${ }^{42}$.

Edukacja oparta na wartościach - niezbędny składnik życia człowieka - „skierowana jest na rozpoznanie, rozumienie, akceptowanie i respektowanie norm i dyrektyw wskazujących na tzw. wartości uchwytne praktycznie i nadrzędne wobec nich wartości ostateczne, którym te pierwsze są bezwzględnie podporządkowane"43.

\section{Zadania edukacji opartej na wartościach}

Zadaniem edukacji - jak twierdzi Czesław Banach - jest przygotowanie młodzieży i dorosłych do dialogu kultur i wartości, do obrony wartości cywilizacji humanistycznej oraz przeciwstawiania się relatywizmowi wartości i upowszechniania opcji minimalistycznych. Podstawową osią kształcenia ogólnego powinna być sprawa wartości, kryteriów i mechanizmów ich wyborów ${ }^{44}$.

$\overline{42}$ Por. A. Maj, hasło: Aksjologia, [w:] K. Chałas, A. Maj (red.), Encyklopedia aksjologii..., s. 85.

43 W. Pasterniak, O dydaktycznej teorii wartości, Wydawnictwo „Bios”, Goleniów 1991, s. 10.

44 Cz. Banach, Edukacja, wartość, szansa, Wydawnictwo Naukowe AP, Kraków 2001, s. 176. 
Jednym z warunków tego rodzaju edukacji jest aktywność aksjologiczna wychowanka, czyli jego otwartość na wartości, koncentracja i celowe zaangażowanie w dążeniu do ich poznania, zrozumienia, interioryzacji, włączenia ich w strukturę osobowości, gotowości ich urzeczywistniania, w tym twórczej realizacji. Natomiast w odniesieniu do nauczyciela - wychowawcy, aktywność ta warunkuje postawy i zachowania, a także sposoby postępowania. W tej kategorii zachowań na pierwszym miejscu stawia się autorytet moralny nauczyciela, który świadcząc o wartościach przez swoje życie, staje się osobą wiarygodną, znaczącą, godną naśladowania. Ważnym czynnikiem rozwijania aktywności aksjologicznej jest personalna relacja wychowawca - wychowanek, przybierająca charakter spotkania, w którym wychowawca wskazuje „drogę” aksjologiczną, „owoce” jej wyboru i towarzyszy wychowankowi w jego wysiłku, odkrywaniu nowych postaci wartości, dokonywaniu wyborów, realizacji wartości - w procesie ich urzeczywistniania. Podstawę tej relacji określa norma personalistyczna ${ }^{45}$. Znaczącym instrumentem oddziaływania pedagogicznego jest dialog między uczestnikami procesu edukacyjnego, zorientowany na poszukiwanie prawdy. Warunkuje on poznawanie i obustronne poszukiwanie dróg rozumienia, wzajemne ubogacanie się, w atmosferze wzajemnego szacunku, poszanowaniu godności osobistej, respektowaniu wzajemnej podmiotowości ${ }^{46}$. W odniesieniu do procesu wychowania, wartości stanowią normatywny system kształtujący praktykę wychowawczą, a zwłaszcza relacje personalne: wychowawca - wychowanek.

\section{Sukces edukacyjny ucznia}

Pojęcie sukcesu edukacyjnego ma charakter jednoznacznie pozytywny, ale bez wątpienia może być różnie rozumiany. Sukces ucznia, to przede wszystkim dokonanie czegoś ważnego dla siebie i innych, to wyczyn, znaczące osiągnięcie, wysoki wynik określonych działań, widoczne i doceniane przez innych efekty, to także powodzenie, sława.

$\overline{45}$ K. Chałas, hasło: Edukacja aksjologiczna, [w:] K. Chałas, A. Maj (red.), Encyklopedia aksjologii..., s. 335.

46 E.K. Wołodźko, Wartości w kształtowaniu osobowości podmiotów procesu wychowawczego, [w:] U. Ostrowska (red.), Aspekty aksjologiczne w edukacji, Wydawnictwo Uniwersytetu Warmińsko-Mazurskiego, Olsztyn 2000, s. 104. 
Dla większości nauczycieli sukcesem edukacyjnym będzie dobrze zdany przez ucznia egzamin, wysokie miejsce w różnego typu konkursach, dostanie się na prestiżowe studia. Dzieje się tak, ponieważ obecnie jakość pracy szkół mierzy się, jak już wspomniano, ilością absolwentów, którzy dostali się na renomowane studia wyższe i na zagraniczne uczelnie. Jest to jednak wąska grupa uczniów, którym się powiodło. Nie można spychać na margines całej rzeszy uczniów, którzy nie mieli tyle szczęścia. Ważne jest, by szkoła nie uczyła biernego przetrwania i godzenia się ze swoim losem, czy brakiem spełnienia. Zadaniem szkoły jest uczenie strategii spełniania się, powinna ona zachęcać do realizacji marzeń i pragnień, uczyć sztuki osiągania celów, budzić kreatywność nawet w małych codziennych działaniach, bo przecież pragnienia i ambicje są różne i nie wszyscy uczniowie marzą o studiach.

Największym edukacyjnym sukcesem jest ten moment, ta chwila, w której uczeń samodzielnie podejmuje trud nad własnym rozwojem. Samokształcenie występuje wówczas, kiedy mając początki opanowane przez kształcenie szkolne, uczeń rozwija samodzielnie wiedzę, poszerza ją o nowe zagadnienia, nieuwzględnione w programie, lub zdobywa nowe umiejętności. W pracy tej uczeń nie tylko przeżywa radość towarzyszącą zdobywaniu wciąż nowych interesujących informacji, ale sprawdza też siebie w różnych formach samodzielnego działania.

Samodzielne podjęcie trudu samokształcenia przez ucznia wymaga dużego wysiłku z jego strony. Dobrze jest, gdy na drodze swego rozwoju, wychowanek spotka prawdziwych nauczycieli, którzy zaszczepią w nim pasję poszukiwania i odkrywania. Chodzi o takich nauczycieli, dla których aktywność dziecka, zainteresowania i ciągle stawiane nowe pytania, nie będą zmorą, od której trudno się uwolnić, lecz staną się początkiem długiego dialogu, na końcu którego wychowanek powie „a teraz ja sam”.

Każdy nauczyciel, który potrafi przejąć się przedmiotem, którego naucza, osiąga w łatwy sposób rzecz w nauczaniu najcenniejszą: wywołuje w swoich uczniach podobne odczucia. Uczniowie wtedy „lubią przedmiot”, chętnie się uczą, a co najważniejsze - przejmują łatwo poglądy, przeświadczenia, zamiłowania i dążenia nauczyciela.

Jak już wspomniano, nie można oddzielić nauczania od wychowania. 
Całość zabiegów wychowawczych nie jest do ujęcia w sztywne schematy, do których mogłyby się stosować ustalone przepisy i zasady. To domaga się od wychowawcy nastawienia twórczego. Zasadza się ono przede wszystkim na pewnej gotowości, ale i zdolności do oryginalności. To zaś polega na umiejętności planowania w dziedzinie wychowania, na własnych poszukiwaniach metod i sposobów oddziaływania na postawy wychowanków, na dostosowanym i umiejętnym podejmowaniu nowych problemów. Twórcze nastawienie nauczyciela udziela się wychowankom, wywołując ich szczególny zapał, energię, zainteresowanie.

Należy także pamiętać, że proces rozwoju ucznia uzależniony jest nie tylko od czynników wewnętrznych (potrzeby) i zewnętrznych (wpływ wychowania), ale także osobowościowych, czyli cech duchowych, decydujących o samodzielnym kierunku rozwoju danego wychowanka.

Podsumowując przeprowadzoną analizę można bez wątpienia stwierdzić, że nauczyciel, który jest wzorem osobowym dla swoich uczniów, ma ogromne możliwości pozytywnego oddziaływania na ich sferę intelektualną, emocjonalną i duchową. A rzetelna realizacja wymagań edukacyjnych daje nie tylko szansę na rozwój, ale jest gwarancją sukcesu edukacyjnego ucznia.

\begin{abstract}
One of the specialities in pedagogy is so-called character pedagogy, also referred to as meeting pedagogy.

This type of pedagogy fits the concept of the „teacher's personal model guaranteeing the educational success of the student". In order to discuss the topic, which aims to scrutinise the relationship between the teacher's attitude and the student's achievements, it is necessary to present two basic issues, each of which consists of four specific parts: issue I. - The teacher as a personal pattern: 1) the concept of a personal pattern, 2) attitude of pro-existence fundamental values in the life and work of the teacher-educator, 3) self-formation through self-education, 4) desirable characteristics of the teacher-educator; and issue II. - Education: 1) the concept of education, 2) values as the basis of education, 3) the tasks of education based on values, 4) educational success.

The analysis proves without a doubt that the teacher, who is a personal role model for the students, has great opportunities to positively influence their intellectual, emotional, and spiritual lives. It should
\end{abstract}


also be remembered that the student's development process is not only a chance for development but also a guarantee of the student's educational success. It is also important that the student's development process depends not only on internal factors (needs) and external factors (upbringing), but also on the student's personality, i.e. spiritual qualities that determine the independent direction of development of a given pupil

\section{Bibliografia}

Banach Cz., Edukacja, wartość, szansa, Wydawnictwo Naukowe AP, Kraków 2001.

Bis D., Misja wychowawcza w ujęciu Romano Guardiniego, [w:] A. Rynio (red.), Wychowanie człowieka otwartego. Rola „Zmystu religijnego" Luigi Giussaniego w kształtowaniu osoby, Wydawnictwo Jedność, Kielce 2001.

Chałas K., hasło: Edukacja aksjologiczna, [w:] K. Chałas, A. Maj (red.), Encyklopedia aksjologii pedagogicznej, Wydawnictwo Polwen, Radom 2016.

Dubisz S. (red.,) Uniwersalny słownik języka polskiego, t. 4, PWN, Warszawa 2003.

Dudzikowa M., Praca młodzieży nad sobą, Spółka Wydawnicza Terra, Warszawa 1993.

Edukacja, [w:] S. Dubisz (red.), Uniwersalny słownik jezzyka polskiego, t. 1, Wydawnictwo Naukowe PWN, Warszawa 2003.

Encyklika Jana Pawła II Redemptor hominis z 4 marca 1979 r.

Gnitecki J., W poszukiwaniu aksjologicznych podstaw edukacji, [w:] U. Ostrowska (red.), Edukacja przełomu wieków wobec kwestii aksjologicznych, Wydawnictwo Uniwersytetu Warmińsko-Mazurskiego, Olsztyn 2001.

Grzywak-Kaczyńska M., Trud rozwoju, Instytut Wydawniczy PAX, Warszawa 1988.

Guardini R., Bóg daleki Bóg bliski, Wydawnictwo „W Drodze”, Poznań 1991.

Jasińska E., Wzorzec osobowy, wzór osobowy, [w:] E. Gigilewicz (red.), Encyklopedia katolicka, t. 20, Wydawnictwo Towarzystwo Naukowe KUL, Lublin 2014.

Jeziorański M.,Wychowawca, [w:] E. Gigilewicz (red.), Encyklopedia katolicka, t. 20, Wydawnictwo Towarzystwo Naukowe KUL, Lublin 2014.

Jougan A., Słownik kościelny łacińsko-polski, wyd. 3, Księgarnia św. Wojciecha, Poznań 1958. 
Jundziłł I., Samowychowanie, [w:] W. Pomykało (red.), Encyklopedia pedagogiczna, Wydawnictwo Fundacja Innowacja, Warszawa 1993.

Jundziłł I., O samowychowaniu, Wydawnictwo Nasza Księgarnia, Warszawa 1975.

Jundzłł I., Aktywizacja dziecka w procesie wychowania, Wydawnictwo PZWS, Warszawa 1966.

Koska W., Katechetyka, Księgarnia św. Wojciecha, Poznań 1993.

Kukołowicz T., Pomagamy w samowychowaniu, Wydawnictwo Nasza Księgarnia, Warszawa 1978.

Łobocki M., Altruizm a wychowanie, Wydawnictwo Uniwersytetu Marii Curie-Skłodowskiej, Lublin 1998.

Maj A., Aksjologia, [w:] K. Chałas, A. Maj (red.), Encyklopedia aksjologii pedagogicznej, Wydawnictwo Polwen, Radom 2016.

Maj A., Wychowanie. Aspekt religijny, [w:] E. Gigilewicz (red.), Encyklopedia katolicka, t. 20, Wydawnictwo Towarzystwo Naukowe KUL, Lublin 2014.

Nowak M., Pedagogiczny profil nauk o wychowaniu. Studium z odniesieniami do pedagogiki pielęgniarstwa, Wydawnictwo KUL, Lublin 2012.

Ostrowska U., Aksjologiczne podstawy wychowania, [w:] B. Śliwerski (red.)., Pedagogika, t. 1: Podstawy nauk o wychowaniu, GWP, Gdańsk 2006.

Ostrowska U., hasło: Wartość, [w:] K. Chałas, A. Maj (red.), Encyklopedia aksjologii pedagogicznej, Wydawnictwo Polwen, Radom 2016.

Pasterniak W., O dydaktycznej teorii wartości, Wydawnictwo „Bios”, Goleniów 1991.

Pastuszka J., Charakter człowieka, Wydawnictwo KUL, Lublin 1962.

Pietrasiński Z., Kierowanie własnym rozwojem, Państwowe Wydawnictwo Iskry, Warszawa 1977.

Rogowski C., Edukacja religijna, [w:] C. Rogowski (red.), Leksykon pedagogiki religii. Podstawy - Koncepcje - Perspektywy, Wydawnictwo Księży Werbistów „Verbinum”, Dragacz 2004.

Siek S., Formowanie osobowości, Wydawnictwo Akademii Teologii Katolickiej, Warszawa 1986.

Sobór Watykański II, Deklaracja o wychowaniu chrześcijańskim.

Sowiński A.J., Samowychowanie, [w:] K. Chałas, A. Maj (red.), Encyklopedia aksjologii pedagogicznej, Wydawnictwo Polwen, Radom 2016.

Sujak E., Samowychowanie, [w:] Cz. Bartnik i in. (red.), Bóg-Człowiek -Świat. Ilustrowana encyklopedia dla młodzieży, Wydawnictwo 
Księgarnia św. Jacka, Katowice 1991.

Słomkowski A., Ku doskonałości, Instytut Chrystusa Króla i Maryi Matki i Królowej, Warszawa 1993.

Słotwińska H., Kształtowanie postaw religijnych na katechezie, Katolicki Uniwersytet Lubelski, Lublin 2004.

Słotwińska H., Samowychowanie i samokształcenie elementami autoformacji, „Paedagogia Christiana” 2007, nr 1(19).

Słotwińska H., Wychowawcza wartość wzorów osobowych, Wydawnictwo Gaudium, Lublin 2008.

Słotwińska H., Wychowanie chrześcijańskie szansą integralnego rozwoju człowieka. Studium z pedagogiki religii, Oficyna Wydawnicza „Impuls", Kraków 2019.

Śliwerski B., Edukacja, [w:] C. Rogowski (red.), Leksykon pedagogiki religii. Podstawy-Koncepcje-Perspektywy, Wydawnictwo Księży Werbistów „Verbinum”, Dragacz 2004.

Tarnowski J., Dojrzałość społeczna jako podstawa i wynik samowychowania, „Ateneum Kapłańskie” 1978, nr 86.

Verhack I., Wychowywać czyli wzbudzać poznanie własnego istnienia, [w:] A. Rynio (red.), Pedagogika katolicka, Oficyna Wydawnicza Fundacji Uniwersyteckiej, Stalowa Wola 1999.

Wołodźko E.K., Wartości w kształtowaniu osobowości podmiotów procesu wychowawczego, [w:] U. Ostrowska (red.), Aspekty aksjologiczne w edukacji, Wydawnictwo Uniwersytetu Warmińsko-Mazurskiego, Olsztyn 2000.

Wylie R., The Self Concept, Oxford University Press, New York 1966.

Wzór osobowy, [w:] J. Wojnowski (red.), Wielka Encyklopedia PWN, t. 30, PWN, Warszawa 2005.

Zalewska W., Kulturoterapia jako edukacja aksjologiczna, [w:] K. Olbrycht (red.), Edukacja aksjologiczna. Wymiary-Kierunki-Uwarunkowania, Wydawnictwo Uniwersytetu Śląskiego, Katowice 1994.

Z listów św. Jana Bosko, [w:] Liturgia Godzin, t. 3, Pallottinum 1987. 